\title{
Tradition Versus Modernity in Laila al-Juhani's The Waste Paradise: An Intertextual Approach
}

\author{
Mohammed Abdullah Abduldaim Hizabr Alhusami \\ Najran University, Najran, Saudi Arabia
}

\begin{abstract}
The aim of this paper is to investigate the issue of intertextuality in the novel Alfirdaws Alyabab (The Waste Paradise) by the female Saudi novelist and short story writer Laila al-Juhani. Intertextuality is a rhetoric and literary technique defined as a textual reference deliberate or subtle to some other texts with a view of drawing more significance to the core text; and hence it is employed by an author to communicate and discuss ideas in a critical style. The narrative structure of Alfirdaws Alyabab (The Waste Paradise) showcases references of religious, literary, historical, and folkloric intertextuality. In analyzing these references, the study follows the intertextual approach. In her novel The Waste Paradise, Laila al-Juhani portrays the suffering of Saudi women who are less tormented by social marginalization than by an inner conflict between openness to Western culture and conformity to cultural heritage. Intertextuality relates to words, texts, or discourses among each other. Moreover, the intertextual relations are subject to reader's response to the text. The relation of one text with other texts or contexts never reduces the prestige of writing. Therefore, this study, does not diminish the status of the writer or the text; rather, it is in itself a kind of literary creativity. Finally, this paper aims to introduce Saudi writers in general and the female writers in particular to the world literature.
\end{abstract}

Index Terms-Waste Paradise, Laila al-Juhani, intertextuality, transtextuality, pastiche

\section{INTRODUCTION}

The Arabic novel emerged late compared to Arabic poetry, which is considered as old as the Arabic language. In Saudi Arabia, the novel has flourished recently and many Saudi female novelists appeared in the literary scene in the 20th and 21st centuries with great works of art: Laila al-Juhani's Alfirdaws Alyabab [The Waste Paradise] is a good example. Laila al-Juhani was awarded several literary prizes. She won the Sharjah Award for Arab Creativity in 1997 for her novel Alfirdaws Alyabab [The Waste Paradise] - the novel which this paper deals with. She has also written three more novels entitled: Always Love Will Remain (1995), Days of Ignorance (2007), and 40 Fi Ma'na an Akbor (2009).

In her novel, Alfirdaws Alyabab [The Waste Paradise], also translated under the title "The Desolate Paradise" by Mandy McClure (Ashour et al., 2008, p. 273) and the title "Barren Paradise" by Jayyusi (Jayyusi et al., 2006, p. 295). Laila al-Juhani dealt with love and betrayal in a conservative society. The novel's plot revolves around three main characters: Saba, the girl represents love and also the victim; Amer represents betrayal and cruelty; and Khalida represents the witness of the story events.

Like other Saudi female writers, al-Juhani highlights ideological and societal bias against women. She criticizes the social norms that make women suffer from marginalization and gender bias. In her novel, The Waste Paradise, alJuhani refers to the injustice of the men to women, whereas in her novel Days of Ignorance, she refers to the injustice of the society to women. Intertextuality, allusions, and quotations in al-Juhani's novel The Waste Paradise support the author's message of criticizing the cultural heritage and social prejudice against women. Barthes (1977, as cited in Allen, 2011) argues that a text is "a tissue of quotations drawn from the innumerable centres of culture" (p. 13). In other words, Barthes reduces the writing act to "quotation" in so far as writing is "quoting" other texts. In so doing, Barthes anticipates Kristeva's theory of intertextuality.

Genette (1997, as cited in Allen, 2011) differentiates between pastiche and parody, as being the two types of relationships, a derived text can have with the text of reference, known as hypotext. Pastiche refers to imitation, among other hypertextual practices, whereas parody refers to transformation. Pastiche and parody are the two most prominent hypertextual genres in imitative writing.

Intertextuality refers to the fact that a text is made up of other texts. It is achieved through such ways and means as citation, transformation, allusion, imitation, repetition, and so on. Kristeva (1980, as cited in Allen, 2011) calls any text an "intertext"; in other words, any text is the intersection of a multitude of other texts, and it exists only through its relation with other texts. A text is produced within a cultural sign system, which conditions its meaning. Intertextuality is often restricted to intentional allusion or references to previous texts through means of quotation or citation. However, the meaning its expounders - Kristeva, Barthes and other French post-structuralist theorists of the 1960s and 1970s gave it is far broader than that. 
Kristeva, Barthes, and the other post-structuralists look upon a text as a linguistic phenomenon deeply rooted in the numerous discursive contexts of its immediate culture and its author. In other words, the essence of a text does not lie in the intention of its author. Barthes (1968) expanded on this central idea in his famous essay The Death of the Author which addresses authorship issues and textual ownership. Barthes symbolically "kills" the author seen as the source of textual meaning - the Author God -, and celebrates the activation or construction of meaning as an enterprise involving the discursive contexts within which the language of the text, the author, and the reader exist. The construction of meaning then takes into consideration a vast network of discursive contexts, all in interconnection. Barthes makes it clear that a text is made of multiple writings drawn from many cultures, and between which there are relations of dialogue, parody, and contestation. As Barthes clearly asserts, the reader's birth must be at the cost of the author's death.

The technique of intertextuality can be traced in al-Juhani's novel The Waste Paradise sparks from the very beginning, the title. This paradoxical title "The Waste Paradise" echoes T. S. Eliot's title "The Waste Land" and John Milton's title "Paradise Lost". As Adam and Eve lost Paradise, Saba lost her own paradise - paradise of love - Her paradise turned to dust, it turned to be barren like Eliot's The Waste Land.

The novel is divided into six chapters, the title of the first chapter is built upon a paradox "The air dies of suffocation", the second chapter is "Details of pain", the third chapter is "An eighth continent subsides", the fourth is "Fall of the flower", the fifth is "The sensitive people will not be left to cry on the balconies", and the last chapter has the title "The reduction of the soul". In the first four chapters, Saba herself tells the story of her life and then dies. In the last two parts, Khalida discovers her fiancé's betrayal and tells the rest of Saba's life story.

\section{LITERATURE REVIEW}

Researchers and critics show a particular interest in the representation of the social status of women in Saudi literature. Indeed, a lot of studies tackle the issue of the condition of Saudi women in contemporary Saudi Arabian literature. Badry (2018) comes up with an overview of a sample of novels by contemporary Saudi female writers that address taboo subjects and challenge prevailing gender discourses fostered by the religious- political establishment. These novels also seek to push for reform and correct the stereotypes images of the Arab woman in Western countries. Therefore, it does not come as a surprise that the majority of the research papers and doctoral dissertations about this issue mainly adopt a sociological approach. As a case in point, Alhazza (2014) studies the marginalization of the Saudi woman in Saudi literary production within the period 1990-2011. Intertextual studies about Saudi Arabian literature do exist.

Hammad (1997) conducted a study entitled "Intertextuality in the Arabic novel, a critical analysis" in the Arabic language. Deheuyels \& Michalak-Pikulska (2006) edited a book entitled "Intertextuality in Modern Arabic Literature since 1967". Adaouri (2012) wrote a book in Arabic language, entitled "Poetic Intertextuality in the Arabic Novel". Seddar (2016) conducted a study on intertextuality in Arabic literary Heritage: A Reading in the Light of the Theory of Transtextuality.

El Sayed (2014) conducted a study on the intertextuality between Imam Abdul Qahir Al Jurjani and Julia Kristeva. He traced the intertextuality in Arabic literature and found that the idea of intertextuality in the Arabic literary heritage could be a literary practice with a plagiarizing touch. Jayyusi in (al-Hazimi et al., 2006) translated anthology of modern Saudi literature. London and selected the title "Barren Paradise" as a translation of al-Juhani's novel Alfirdaws Alyabab. Phillips (2004) translated Laila al-Juhani: "Jeddah is Sinking" - an excerpt from The Waste Paradise" in Banipal, Vol. 20. al- Mana in (Ashour 2008) conducted a study about Arab women writers in Arabian Peninsula and Gulf, translated by Mandy McClure who selected " The Desolate Paradise " as a translation to al-Juhani's novel Alfirdaws Alyabab. Hamed bin Aqeel (2006) conducted a hermeneutic-critical study of Laila al-Juhani's novel The Waste Paradise. He divided his study into five sections: the first is the Desolate Individual, the second is the Desolate society, the third is the Waste City, the fourth is the Universe, and the fifth is the Waste Civilization. He presented a general introduction to the study of the novel. He referred to the relationship between John Milton's Paradise and Laila a-Juhani's Paradise in general. If paradise is existent, it is waste, and when non-existent, it is lost. Khalid Aldakheel (2014) published a paper in the 7th International Conference on Literature, 9-12 July 2014, entitled "The Power of Men over Women in Layla alJuhani's novel al-Firdaws al-Yabab (The Waste Paradise)".

Beside all these studies about intertextuality, there is no research dealing with the subject of intertextuality in Laila al-Juhani's The Waste Paradise, the novel under study in this paper. And yet, researchers resort to other approaches to explore the issue of the place of Saudi women in fiction. For instance, Najlaa Aldeeb uses a gynocritic-intersectional approach to study the condition of the Saudi woman in Raja Alem's novel The Dove's Necklace. This approach is based on gynocriticism, a term coined by Showalter (1981) to undermine the feminist approach to literary texts, and on intersectionality, a concept that expresses the way factors such as gender, race, religion and social class cause social discrimination.

\section{RESEARCH METHODS}

This study is rooted in the framework of the intertextual approach and makes use of the western critical writings which considers the term intertextuality as one of the critical canons in literary criticism. 


\section{CONCEPT OF INTERTEXTUALITY IN ARABIC LITERATURE}

The concept of intertextuality in its modern critical sense was not present in old Arabic criticism. However, it has some hints in the Arabic heritage. El Sayed (2014) mentioned that the first seed of intertextuality in Arabic literature can be traced back in the poetry of Imru Al Qais, Antara, Kaab bin Zuhair, and Tarfa bin Al-Abd. He added that the idea of intertextuality in the Arabic literary heritage could be a literary practice with a plagiarizing touch, but in modern Arabic criticism, the term has been translated into Arabic in various ways with various meanings.

\section{INTERTEXTUALITY IN AL-JUHANi'S THE WASTE PARADISE}

\section{A. The Religious Intertextuality}

The religious intertextuality is present from the first chapter of the novel, 'The air dies of suffocation'. The writer uses religious phrases to link the events of the novel with similar events of stories told in the Holy Qur'an. Saba, the main character, has transgressed the social and religious taboo; therefore, a feeling of guilt made her recall religious phrases. In the first chapter, Saba discovers her lover's betrayal and wishes for the end of the world: "And Michael1 blows the horn, and the details of my slaughtered love are laid open and are resurrected naked" (al-Juhani, 1999, p. 5). Such phrases echo verses of the Holy Qur'an: "The Trumpet will be sounded and - and behold! - they will rush out to their Lord from their graves" (The Qur'an 36: 51), "When the records of deeds are spread open" (The Qur'an 81: 10).

When Saba sees her traitorous lover, Amer, with her friend, Khalida, she wishes to warn her, but she cannot: "For God's sake, do not open the doors of torment with your hands. But I fall seventy autumns in the fire" (al-Juhani, 1999, p. 6). The phrase "I fall seventy autumns in the fire" is mentioned in the hadith of the prophet Mohamed: "Indeed a man may utter a statement that he does not see any harm in, but for which he will fall seventy autumns in the Fire." (AtTirmidhi, 2007, p. 351)

Saba does not want her friend Khalida to go through the same experience, but she herself thinks she deserves to fall seventy autumns in the fire because of her guilt and her incapacity to warn Khalida.

She prays: "Where are you God? Where are you? Why do you leave me to this world that would sullenly frown at me?" (al-Juhani, 1999, P. 25). It is taken from the prophet's Mohammed supplication: "You are the Lord of the weak, and You are my Lord. To whom You leave me? To a foe who would sullenly frown at me" (Al-Mubarakpuri, 2007, p. 126)

It clearly appears from the analysis of The Waste Paradise that the fundamental text of Islam, known as The Qur'an, is a hypotext to al-Juhani's novel in the sense that it serves as the source of the discourse of some characters and shapes their idiolect. al-Juhani uses it in the novel both explicitly and allusively: "I will not be there, and you, my baby, will not there. Moreover, this ramshackle world may not be there. . It perhaps will be a thing long forgotten. Maybe a flood sweeps it; a flood without Noah floods the world and wash it from humans and sins" (al-Juhani, 1999, p. 55-56). In these lines, Saba, the main character of the story, remembers Mary in the Qur'an and cries like her: "and, when the pains of childbirth drove her to [cling to] the trunk of a palm tree, she exclaimed, 'I wish I had been dead and forgotten long before all this!" (The Qur'an 19: 23). Saba wishes the world were "a thing long forgotten" and swept. She could not face society as Mary did. Mary did not commit any sin; she did not miscarry her baby like Saba either. Moreover, her miraculous son, the prophet Jesus was her lawyer. Saba has a baby from an adulterous relationship with Amer, her beloved, who betrays her later and says to her: "Love is a dunghill". Saba strongly believes that the world is a place of sins, and she wishes a flood like the one Noah and his people underwent washed it. She makes an allusion to the story of Noah in the Qur'an, but she does not quote the text. Saba's words, "The sea is burned in Jeddah. It is filled like my heart" (al-Juhani, 1999, p. 59) reminds a verse in the Qur'an "And by the sea kept filled (or it will be fire kindled on the day of resurrection" (The Noble Qur'an 52: 6).

When Khalida discovers the reality, she bewails her friend, Saba, who was the victim of betrayal and love. Khalida prays to her, "Let God's forgiveness be a cloud that the angels now drive to clouds pour down the rain and hail, roses, little birds, and olives and palm trees, and dense orchards, and fruit and fodder." (al-Juhani, 1999, P. 77). Khalida's prayer is taken from verses in the Holy Qur'an "Then let man look at his food. We pour forth water in abundance. And We split the earth in clefts. And we cause therein the grain to gro. And grapes and clover plants. And olives and datepalms. And gardens dense with many trees. And fruits and herbage" (The Noble Qur'an 80: 24-31).

Khalida remembers going out with Saba to the sea, but now she addresses the sea to split up to Saba. "Moses called, and the sea was split, each part was like a huge mountain." (al-Juhani, 1999, P. 79). She may want Saba to escape as Moses did. "And We revealed to Moses: 'Strike the sea with your staff.' It parted- each side like a mighty mountain" (The Qur'an, 2004, 26: 63).

The presence of religious expressions in the novel indicates that through the character of Saba, the woman lives in conflict with herself because she lives in a conservative society and wants to be free from the restrictions of cultural heritage, but she is tied to it. Saba implicates the oppression of women when she says to her friend, Khalida: "Isn't that

\footnotetext{
${ }^{1}$ The writer said that Michael blows the trumpet, but it is familiar among the common people that, it is the Angel, Israfil who will blow the trumpet. However, this name, Israfil, is not mentioned in the Qur'an or in the Authentic Hadiths.
} 
an agony to be a woman?" (al-Juhani, 1999, p. 8). The novel used words and phrases from the Qur'an not merely to give strength to the text, but also to evoke the scenes and images similar to the situation that Saba experiences.

\section{B. Historical Intertextuality}

The Waste Paradise builds up dialogic relationships with history. Literary discourse draws on historical discourse, as illustrated by the historical references and allusions in the characters' ideas and thoughts: "Paradise Lost is behind me, and the sea is in front of me" (al-Juhani, 1999, p. 29). These words recall the famous words of the Muslim commander Tariq bin Ziyad who invaded Spain in 711 and said: "The Sea is behind you, and the enemy is in front of you". The writer evokes the history in her mind and the fall of cities. She compares Saba's tragedy with the fall of Andalusia and Jerusalem. "Leave her, she is cursed, resembles herself to Andalusia and Jerusalem" (al-Juhani, 1999, p. 33).

"And you, Saba, another Granada fell yesterday" (al-Juhani, 1999, p. 75). In this line, there is historical and literary intertextuality. [Historically, it refers to the fall of Granada; and literary, it refers to Darwish poem "The Fall of Granada" The reference to the fall of Granada anchors the narrative not only in history but also in literature as it evokes Darwish's poem "The Fall of Granada".

The writer also recalls the history of English literature: "Paradise Lost? From where this name came? From which book I picked it? From which story I read? The short history of English literature by Ifor Evans" She specifies where she got this name: from "Miltons' epic Paradise Lost which was published in 1667 and became a symbol for every dream that collapses" (al-Juhani, 1999, Pp 34 -35). From Paradise Lost book IV, al-Juhani quotes:

AMe miserable! which way shall I fly

Infinite wrath, and infinite despair?

Which way I fly is Hell; myself am Hell;

And, in the lowest deep, a lower deep

$\ldots \ldots$

O, then, at last relent: Is there no place

Left for repentance, none for pardon left?

So farewell, hope; and with hope farewell, fear;

Farewell, remorse! all good to me is lost.

(al-Juhani, 1999, p. 35)

In the novel, Saba is implicitly compared to Eve and Amer to Satan: "Paradise Lost, Adam, Eve and Satan. Always Adam and Eve, even the universe began with Adam, Eve a Satan and paradise lost" (al-Juhani, 1999, P. 36)

This comparison is further reinforced by the parallel the narrator makes between the story of Saba and Amer and that of Adam, Eve, and Satan: "Finally, Satan won, Adam and Eve have lost the paradise. Now I hear him laughing near the window. He laughs and laughs whereas I am spread out upon the sofa." (al-Juhani, 1999, pp. 38-39).

\section{Literary Intertextuality}

Saba describes her embryo: "Irises without Eyelids without eyelashes" (al-Juhani, 1999, p. 14). Similarly, Al-Sayyab depicts Baghdad tyrant during his time as a gruesome creature when he says in his poem Vision in 1956: "Eye without eyelids" (Al-Sayyab, 2000, p. 87). Nevertheless, Saba, the main character, does not depict her embryo as a gruesome creature, but she was crying her incomplete fetus she was going to miscarry. Or she may depict the torn fetus when that woman aborts it.

Saba comments on the painful end of her love for Amer and alludes to her life as a Paradise Lost. "Everything finished and vanished in the abysmal depths even the paradise lost" (al-Juhani, 1999, p. 27). The writer alludes to Milton, Darwish, and Unsi al-Hajj. "Did Unsi al-Hajj say: what have you made with the gold, what have you done with the rose". (al-Juhani, 1999, p. 42). Here, She alludes to the title of a book by Unsi al-Hajj.

An analysis of The Waste Paradise enables us to identify a co-presence of Ernest Hemingway in his story The Snows of Kilimanjaro in al-Juhani's novel, notably through the comparison of love to dunghill: "Didn't I say to you, Saba, love is dung, and I am its cock that crows?" (al-Juhani, 1999, pp. 43- 44). Indeed, Harry makes the same comparison in Hemingway's novel: "Love is a dunghill," said Harry. "And I'm the cock that gets on it to crow." (Hemingway, 1936, p. 16) Moreover, in the Rob Roy Movie 1995, by the screenwriter Alan Sharp, Archibald Cunningham said the exact phrase to Betty, the woman that she loved; and became pregnant of his child: "Love is a dunghill, Betty, and I am but a cock who climbs upon it to crow". In fact, the idea of al-Juhani's novel is based on this scene of the movie.

In The Waste Paradise, Saba's friend Khalida hates August and describes it as a cruel month and a tyrant because Saba died this month, August: "August is cruel, stingy and despotic" (al-Juhani, 1999, p. 71). Khalida's abhorrence for the month of August much recalls T. S. Eliot's aversion for the month of April in his poem The Waste Land: "April is the cruelest month"

The title of al-Juhani's novel "The Waste Paradise" is a parody of the title of Eliot's poem "The Waste Land". The phrase "Waste paradise" is an oxymoron as a paradise is opposed to a waste or barren land. The paradise fictionalized in al-Juhani's novel is not a "paradise lost" like Milton's; it is not a "waste land" like Eliot's either. This paradox title expresses the significant shift in Saba's life after she becomes pregnant and gets rejected by her boyfriend, who denies being the father of the child she is carrying. Therefore, her paradise - the place where she used to meet her boyfriend - 
becomes a waste paradise, and her life and future in general turn into a barren existence. The invocation Saba makes expresses her suffering: "My God, take me back to my innocence, nightingale" (al-Juhani, 1999, p. 11). Saba borrows her words from Darwish's verse: "My God, bring me back to my homeland, Nightingale".

Sometimes, al-Juhani explicitly mentions the name of the writer whom she quotes: "Darwish returned and then left". Her phrase "Granada is for singing, so sing" (al-Juhani, 1999, p. 75) is taken from Darwish poem "The Fall of Granada". Khalida remembers fond memories with Saba; she addresses Saba after her death: "There is a line you quote it from Mahmoud Darwish, and you leave it without flowers, decorations or branches:

And there is no longer a present left

To let me pass, tomorrow, close to yesterday2 (al-Juhani, 1999, 80)

\section{Folkloric Intertextuality}

Folkloric intertextuality is also present in The Waste Paradise. The writer includes a stanza of folk songs for children from the Hijazi folklore son, Doha ya doha:

Doha ya doha

And they built the Kabah

My grandpa traveled to Mecca

He got me some cake

The cake is in the closet

And the closet needs a key

And the key is with the carpenter

And the carpenter wants money

And the money is with the bride

And the bride wants to have a baby boy (al-Juhani, 1999, pp. 54-55)

She was dreaming of singing such a song to her baby, but she addressed herself "I will never be a bride and will never have a baby" (al-Juhani, 1999, pp. 54-55)

In the novel, there is also intertextuality to the character of Cinderella and to Ninja Turtles. "Their children, who know about the Ninja Turtles, and like Pocahontas (a Native American woman) no innocence on their faces... their rooms are full of her pictures ..... they dream of Cinderella and Mermaid who loved the young prince and sacrificed her voice to be close to him" (al-Juhani, 1999, p. 75)

\section{CONCLUSION}

A text is not an original product of one author according to the Kristeva, the novel certainly includes many textual overlaps. Laila al-Juhani's The Waste Paradise clearly evidences this fact, as the study of her novel shows that the notion of intertextuality is at the core of its poetics. Intertextuality is primarily the way al-Juhani uses to exposes the conditions of Saudi women, the conflict these women experience, notably openness to Western culture and conformity to their own culture, tradition and religion, all of which are constraints to their self-fulfillment and their empowerment. Laila al-Juhani's novel The Waste Paradise resorts to various types of hypotexts that serve as source of discourse. Religion, literature, history, folklore, myth are as many types of hypotexts that contribute to the representation of Saudi women through intertextuality. The list is not exhaustive as Laila al-Juhani's even resorts to intercultural intertextuality in her novel, notably when she referred to 'Adam and Eve', 'Thamudic inscriptions', 'Moses and Pharaoh', 'Tariq bin Ziyad', 'Pocahontas' (a Native American woman during the American colonial period), the 'Inquisition', 'Christopher Columbus', the 'Fall of Granada', and 'Jerusalem'. As shown in this study, intertextuality does not diminish the status of the writer or the text; rather, it is in itself a source of creativity.

\section{REFERENCES}

[1] Adaouri, S. (2012). Asheriyah fi Ariwayah Alarabiyah [Poetic Intertextuality in the Arabic Novel]. Cairo: Roueya Publish \& Distribution.

[2] Aldakheel, K. (2014, 9-12 June). The Power of Men over Women in Layla al-Juhani's Novel al-Firdaws al-Yabab (The Waste Paradise). 7th Annual International Conference on Literature. Athens, Greece.

[3] Aldeeb, N. R. (2018). A Gynocritic-intersectional reading of Raja Alem's the Dove's Necklace. in Arab World English Journal for Translation and Literary Studies 2. 1, $135-144$.

[4] Alhazza, H. M. S. (2014). Social marginalisation in the Saudi novel between 1990 and 2011. [PhD Thesis. University of Manchester].

[5] Al-Hilali, M. T. and M. M. Khan. (1998). The Noble Qur'an: English translation of the meanings and commentary. Madinah: King Fahd Complex for The Printing of the Holy Qur'an.

[6] Al-Juhani, L. (1999). Alfirdaws Alyabab [The Waste Paradise]. Germany: Al-Kamal Verlag.

[7] Al-Juhani, L. (2004). Laila al-Juhani: Jeddah is sinking - an excerpt from The Waste Paradise. (C. Phillips, Trans.). Banipal 20, p. 92.

[8] Allen, R. (1982). The Arabic novel. New York: Syracuse University Press.

\footnotetext{
${ }^{2}$ These lines were taken from Mahmoud Darwish poem "I am one of the kings of the end" translated by Shahid Ali Agha (Agha, 2009, p. 304).
} 
[9] Allen, G. (2011). Intertextuality. London and New York: Routledge.

[10] Al-Mubarakpuri, S. (2007). Ar- raheeq al makhtum [The Sealed nectar]. Riyadh: Darussalam.

[11] Al-Sayyab, B. S. (2000). Al amal ash shiriyat al kamilah [The Complete poetical works]. Beirut: Dar Al-Awdah.

[12] Aqeel, H. (2006). Fiqh alfawda: Dirasah naqdiyah tawiliyah fi rewayat alfirdaws alyabab [Jurisprudence of chaos: A hermeneutic-critical study of Laila al-Juhani's novel The Waste Paradise]. Beirut: Dar Al Kounouz.

[13] Ashour, R., Ghazoul, F. J., \& Reda-Mekdashi, H. (Eds.). (2008). Arab Women Writers: A Critical Reference Guide, 1873-1999. (M. McClure, Trans.). Cairo: The American University in Cairo Press.

[14] At-Tirmidhi, A. M. (2007). Jami At-Tirmidhi. [al-Tirmidhi's Compilation] (Abu Khaliyl, Trans.). Riyad: Darussalam.

[15] Caiani, F. (2007). Contemporary Arab fiction: Innovation from Rama to Yalu. London: Routledge.

[16] Badry, R. (2018). Countering prevailing discourses with literary creativity: Contemporary Saudi women novelists' drive for change. Synergy 14. 1, 100-117.

[17] Deheuvels, L., B. Michalak-Pikulska, P. Starkey \& M. Thompson (eds.). (2006). Intertextuality in modern Arabic literature since 1967. Durham: Durham University.

[18] El Sayed, A. R. (2014). Intertextuality between Imam Abdul Qahir Al Jurjani and Julia Kristeva. In A. Atiyah Abdulkareem \& M. Sayed Mohammed Alsameen (Eds.) Researches of the first international scientific conference of the Faculty of Arabic Language in Asyut: Imam Abdul Qahir Al Jurjani and his efforts in enriching Arabic Language 2014 (pp.1386 - 1434) Al Azhar University.

[19] Hammad, H. M. (1997). On the intertextuality in the Arabic novel: A critical analysis. Egyptian General Book Authority.

[20] Jayyusi, S. K. (ed.). (2005). Modern Arabic fiction: An anthology. New York: Columbia University Press.

[21] Jayyusi, S. K., M. Al-Hazimi \& E. Khattab (eds.). (2006). Beyond the dunes: An anthology of modern Saudi literature. London: I. B. Tauris.

[22] Laurenson, D. \& A. Swingewood. (1972). The Sociology of Literature. London: Mac Gibbon and Kee.

[23] Mosteghanemi, A. (2008). Memory in the Flesh. London: Publisher Arabia Books Ltd.

[24] The Qur'an. (M. A. S. Abdel Haleem, Trans). (2004). Oxford: Oxford University Press.

[25] Showalter, E. (1981). Feminist criticism in the Wilderness. Critical Inquiry: Writing and sexual difference. 8. 2, 179 - 205.

Mohammed Abdullah Abduldaim Hizabr Alhusami, a Yemeni national, works at Najran University, KSA, as an assistant professor of English literature. He has been teaching at the College of Science \& Arts, Sharurah, Najran University since 2012. He earned his $\mathrm{PhD}$ in comparative literature from University of Hyderabad, India in 2011.

ID ORCI: http://orcid.org/0000-0003-3472-8481 